HSTC Bulletin

Journal of the History of Canadian Science, Technology and Medecine

hstc

Revue d'histoire des sciences, des techniques et de la médecine au Canada

bulletin

\title{
The Macoun-Merriam Connection
}

\section{William A. Waiser}

Volume 6, numéro 1 (20), janvier 1982

URI : https://id.erudit.org/iderudit/800129ar

DOI : https://doi.org/10.7202/800129ar

Aller au sommaire du numéro

Éditeur(s)

HSTC Publications

ISSN

0228-0086 (imprimé)

1918-7742 (numérique)

Découvrir la revue

Citer cet article

Waiser, W. A. (1982). The Macoun-Merriam Connection. HSTC Bulletin, 6(1),

3-9. https://doi.org/10.7202/800129ar

Copyright (C) Canadian Science and Technology Historical Association / Association pour l'histoire de la science et de la technologie au Canada, 1982
Ce document est protégé par la loi sur le droit d'auteur. L'utilisation des services d'Érudit (y compris la reproduction) est assujettie à sa politique d'utilisation que vous pouvez consulter en ligne.

https://apropos.erudit.org/fr/usagers/politique-dutilisation/ 
THE MACOUN-MERRIAM CONNECTION

\author{
W.A. Waiser*
}

(Received 9 March 1981. Revised/Accepted 13 January 1982.)

In January 1882, Professor John Macoun became botanist to the Geological Survey of Canada. It was a significant appointment for both the man and the government agency. Over the past ten years, Macoun had been deeply involved in the debate over the suitability of Western lands for agriculture. 1 Now, at the age of fifty, he was given the chance to fulfill his life-long ambition and devote himself exclusively to the study of natural history. The Survey, for its part, was finally taking steps to uphold its biological duties which had largely been given only passing interest up until this time. Thirty years later, when Macoun retired, the Biological Division boasted the finest collection of Canadian flora and fauna in the country, while its knowledge of these resources was unsurpassed.

Macoun's period of tenure at the GSC coincided with the great reawakening of the imperialist sentiment in Anglo-Canadian relations. Indeed, it has been recently suggested that 'as the concept of a Canadian nation began to take shape in the glow of the British revival of the imperial idea, the worlds of British and Canadian Science ... came together in a number of initiatives, programmes, celebrations and institutions. 2 The national scientific community of Canada was inspired by the heady ideal of furthering the interests of the British Empire and consequently, the influence of American science was restricted.

Imperial sentiment aside, the experience of John Macoun suggests a somewhat different picture. Although he described himself as a staunch conservative and ardent imperialist and regularly expounded on the virtues of the British connection, Macoun relied almost exclusively on American natural scientists not only to examine and assess his collections but also to direct his field work. The great strides made by the Biological Division during this period were largely the consequence of Macoun's phenomenal collecting efforts and his collaboration with American natural scientists.

Macoun corresponded with a number of American naturalists but the best example of the extent of Canadian-American cooperation is his twenty-five-year professional friendship with the mammalogist, C. Hart Merriam. Chief of the Division of Economic Ornithology and Mammalogy (later Bureau of Biological Survey) in the US Department of Agriculture, Merriam was roughly Macoun's counterpart. Both men, in fact, were

* University of Saskatchewan. 
strikingly similar in personality and character. Dedicated field workers, they were motivated by a strong desire to complete a nationwide survey of their respective countries. They were also stubborn, at times arrogant, individuals who valued their own work above almost everything else, and because they had limited financial and manpower resources at their disposal, they were willing to go to almost any length to see it carried out. 3

Merriam had first met Macoun in May 1884 at the Montreal meeting of the British Association for the Advancement of Science. At its conclusion, he took advantage of his proximity to ottawa to visit the Survey headquarters before returning to New York. Merriam later informed Macoun that he 'had learned enough to well repay me for the loss of time.' 4 . In the same letter, he could not resist the temptation to take issue with Macoun's views on the matter of creation and lectured him at length. He then closed on a complimentary note, describing his new Canadian colleague as 'a man of extraordinary experience in the field, of unusual powers of observation, of exceptional familiarity with the forms of life scattered over half a continent.' Merriam had clearly sensed during his brief visit to Canada the importance of flattering Macoun's ego.

Merriam had good reason not to offend Macoun; he needed him. From the outset of his appointment to the Department of Agriculture, Merriam had argued that the economic impact of birds and mammals could not be properly assessed unless their range and habits were known. This concern with the ecology of wildlife quickly developed into a full-scale study of the biogeography of North America.5 Given the sheer size of the project, any information or specimens that the Survey could provide were most welcome, and Merriam actively encouraged Macoun to avail himself of his services. This he began to do in 1885, sending Merriam birds and mammal specimens, along with his field notes. Merriam, in return, did much more than simply identify and assess the significance of Macoun's collections. Since it was to his benefit to improve his field methods, he regularly sent him technical information, ranging from the proper preparation of mammal skins to forms for noting the arrival of birds during spring migration, as well as the revolutionary cyclone trap for capturing small mammals. 6 Merriam also put Macoun in touch with other prominent American scientists. It was through him that Doctors Stejneger and Bean of the Smithsonian began to examine his reptile and fish collections respectively.

Macoun, in turn, needed the knowledge and expertise of such men as Merriam. Although initially hired as botanist to the GSC, he was named Dominion Naturalist in 1887 and was charged with the task of collecting in all areas of natural science, except entomology. Apart from his work on plants and birds, however, Macoun's natural history studies up to this time had essentially been based on what he chanced upon in the field. He was little more than an enthusiastic amateur. It was therefore vital that Macoun learn the best field techniques since he now had to collect as thoroughly and widely as 
possible during his limited time in any one area. For Macoun to seek the assistance of American naturalists in his new position of Survey Naturalist was also natural in light of his botanical work. Although his interest in plants was initially encouraged by the eminent British botanist, sir William Hooker, he had corresponded with American specialists ever since he began to take his botanical studies seriously. Indeed, throughout the $1870 \mathrm{~s}$ and $1880 \mathrm{~s}$, his collections increasingly came under the scrutiny of these men. This trend was not simply a consequence of the great upswing in American botany during this period. The Professor had become increasingly disenchanted with British botanists who failed to acknowledge receipt of his specimens let alone name them. Macoun was thus acting out of habit when he turned to the scientific community south of the border for assistance.

Within ten years, a strong professional bond had been created between the two scientists. Because of Merriam's and other American scientists ' invaluable help in naming specimens, Macoun was able to devote increased attention to his field work and collect on such a large scale. Had he been solely dependent on his own efforts for determining his collections, it is doubtful that he would have attempted to undertake a catalogue of Canadian birds at this time. Then again, Macoun was not one who easily admitted his shortcomings. When his appointment as Dominion Naturalist was questioned, he flatly told Merriam, 'I have done more ornithological work in Canada than any other single man and ought to know something about our birds, but you people are ignorant of this and cannot be blamed. 17

His American colleague also greatly benefitted from the relationship, in that Merriam was usually the first mammalogist to work over Macoun's annual collecting efforts. Often, the quality of specimens suffered from Macoun's attempt to collect as much as possible in the field. Acknowledging the receipt of a particular specimen in 1889, Merriam commented, 'The remains look as though the skull hagd been placed on an anvil and hammered for an hour or two. 18 Merriam, however, was happy to receive whatever came his way, since he depended upon Macoun for much of his information about the geographical distribution of Canadian mammals. Unfortunately though, Macoun came to be taken for granted. In writing to Macoun before the start of the 1890 field season on the Pacific Coast, Merriam remarked, 'Of course you will make collections of mice, shrews and other small mammals, and obtain as much information as possible concerning the distribution of all species.' 9 It eventually reached the point where Merriam sent an annual shopping list prior to the botanist's departure for the field.

The value of the Macoun-Merriam connection was not limited to the exchange of biological specimens and related information. It proved to be rather effective in manipulating Macoun's boss, the Director of Survey Dr A.R.C. Selwyn. In the early 1890s, operating on the assumption that temperature was a prime factor in governing the distribution of mammals, Merriam decided to create life zone maps for North America. 10 
Such an undertaking required detailed field observations and, clearly, Macoun was considered the major source of information for Canada. The years 1893-1894, however, were particularly difficult financially for the $\mathrm{GSC}^{\mathrm{ll}}$ and it appeared doubtful whether Macoun would be able to carry out his proposed examination of southern Assiniboia, an area that Merriam was particularly interested in, given his work in neighboring Montana. Meeting in Boston in November 1893, the pair took it upon themselves to remedy the situation.

Their plot was set in motion in early January 1894. In a confidential letter to Merriam, Macoun advised:

Your letter to $\mathrm{Dr}$. Selwyn came in due course and as usual he did not "catch on" to your meaning... He showed your letter to me but thought we knew enough about the animals of the prairie. I told him we had general knowledge but not particular... I am not aware whether he has answered you or not and would be glad if you would write me a note regarding your intended work and what you would be glad we could do for you. Do not refer at all to this letter or say anything about our conversation but ask me or tell me anything you choose. I will take your letter to Dr. Selwyn at once and if he does not agree with me I will go to the minister and have it done...I have fully made up my mind what to do next year or rather season, and will see that I am allowed to do the work as I wish. 12

In response, Merriam sent a formal letter to the Professor, in which he briefly outlined his work and then asked a series of very specific questions about the limits of particular species. 'Perhaps no biological work in Canada,' the mammalogist concluded, 'is more important at present than determining the northern boundaries of distribution of a number of

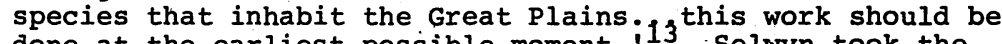

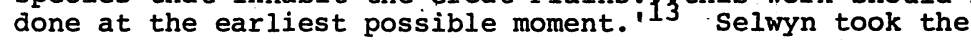
bait. On 8 February Macoun reported back to Merriam that the Director. would not stand in his way if a detailed natural history examination of the prairies was thought necessary. 14

Ironically, before Macoun left for the West; there was almost a falling out between the two conspirators. In December 1893, Macoun received an enthusiastic letter from Samuel Rhoads of the Academy of Natural Sciences in Philadelphia. Rhoads offered to write a manuscript about the mammals of British Columbia based on the Professor's collections. 15 not received that same month a note from Merriam advising him that the identification of specimens would require more time because of his increased workload.16 In the winter of 1894, Rhoads continued to write Macoun, emphasizing the need to press ahead with the project and warning that Merriam would never return the mammai skins.

It was obvious from Rhoads' letters that he was trying to divert Macoun's specimens away from Merriam. The Professor, 
nonetheless, had the opportunity to test the validity of Rhoads' accusation. In preparation for that season's field work, Macoun wanted to examine the skin collections from the previous year in order to become familiar with them. Selwyn, moreover, preferred that Macoun's specimens be returned to the Survey during his absence in the field. Citing these reasons, the botanist asked Merriam on 29 March 1894 to return, within two weeks, all mammal skins belonging to the Survey.17 Five days later, before receiving a reply, he dashed a quick note off to Rhoads, syggesting that he would send him a few specimens that fall. 18 Merriam's reply arrived shortly thereafter. In a brief, tersely-worded letter, he hinted that he was aware of Rhoads' behind-the-scene intrigues and that he no longer wanted to examine any more specimens.19 Macoun was thoroughly shaken by the mammalogist's reply; he had been found out. He did his best, however, to put up an innocent front, arguing in a return letter that 'there is no truth in the statements you have heard. 20 Merriam did not take issue with the Professor's explanation but seemed satisfied that he had made his point. When he returned the specimens, he tried to repair the friendship by suggesting that he might prepare a special report on Canadian mammals.21 The professor was greatly relieved and promised to return the mammal skins in the fall. The incident had such an impact on Macoun that two years later he still felt it necessary to assure Merriam that he was the only mammalogist to examine his collections. 22

In 1900, with the publication of part one of his Catalogue of Canadian Birds, 23 Macoun now turned his attention to the production of a similar work on Canadian mammals; despite his intentions, Merriam never did write the special Canadian mammal report that he had proposed in 1894. Macoun and his field assistant, William Spreadborough, consequently devoted a greater part of their field work over the next few years to the collection of mammals. For Merriam, the turn of the century brought frustration. Under the Roosevelt administration, the emphasis of the Biological Division was shifted to practical research on agricultural problems, while Merriam was called as an expert witness before various Congressional committees. Unable to study what he desired, he eventually, resigned in 1910 to become a Smithsonian research associate.24

The Macoun-Merriam connection in the 1900 s was therefore largely concerned with the naming of Macoun's annual collecting efforts. Yet even this work was a great source of aggravation to the manmalogist. Merriam was continually complaining about the third-rate quality of Macoun's collections and at one point in 1906 became so exasperated that he sent him sample skins, as well as skinning and labelling instructions 25 - the same technical information that had been sent at the beginning of their friendship. Such criticism, however, turned to admiration when Macoun replied by graphically outlining the meagre facilities and appropriation that were available for his work. 26 These conditions were partly responsible for the Professor's failure to complete the mammal catalogue by the time of his retirement in 1912 . 
For the better part of his thirty-year tenure at the GSC, John Macoun was charged with the formidable task of uncovering the animal life of the northern half of the North American continent. Although driven by an untiring energy and infectious enthusiasm, the task was too much for the botanist, let alone any natural scientist, and he was forced to seek assistance from specialists. Turning to the scientific community south of the border, instead of seeking help from across the ocean, was only natural in that Canadian and American scientists shared similar environments and similar species. Their proximity also facilitated the exchange of specimens and related scientific information. Macoun's twenty-five-year professional friendship with $C$. Hart Merriam of the US Department of Agriculture was only one of several such relationships that he had with American natural scientists. 27 In almost every such instance, Macoun fulfilled his duties with the assistance of American naturalists; they not only classified his specimens but advised him where to collect and what to collect. It would appear that in the case of John Macoun's work the influence of American science during this period was much greater than is believed to be the case for Canadian scientific endeavours in general. Macoun's enumeration of Canada's animal wealth may have been inspired by the heady ideals of empire, but it was only with American assistance that his wide and varied collections received the attention that they richly deserved.

\section{NOTES}

1. See W.A. Waiser, 'Macoun and the Great North-West,' (MA thesis, University of Saskatchewan, 1976); D. Owram, Promise of Eden (Toronto, 1980), Chapter 7.

2. Vittorio De Vecchi, 'Science and Government in the Nineteenth Century,' (PhD Dissertation, University of Toronto, 1978), 4 .

3. See. John Macoun, Autobiography of John Macoun, M.A. (Ottawa, 1922); K.B. Sterling, Last of the Naturalists. The Career of C. Hart Merriam. (New York, 1977).

4. Ottawa, National Museum of Natural Sciences (NMNS), Vertebrate Zoology Division. Anderson Papers, Merriam to Macoun, 25 May 1884.

5. sterling, op. cit., 28.

6. NMNS, Anderson papers. Merriam to Macoun, 21 July 1885.

7. Ottawa, National Museums of Canada Library (NMCL), John Macoun letterbooks. Macoun to Merriam, 6 April 1888.

8. NMNS, Anderson papers. Merriam to Macoun, 17 January 1889 .

9. NMNS, Botany Division, Historical Correspondence. Merriam to Macoun, 2 April 1890. 
10. Sterling, op. cit., 231 .

11. Much of the Survey's financial troubles during this period were caused by the transfer of power from the Conservative to the Liberal party.

12. NMCL, John Macoun letterbooks. Macoun to Merriam, 4 January 1894 .

13. NMNS, Anderson papers. Merriam to Macoun, 28 January 1894 .

14. NMCL, John Macoun letterbooks. Macoun to Merriam, 8 February 1894.

15. NMNS, Anderson papers. Rhoads to Macoun, 4 December 1893 .

16. Ibid. Merriam to Macoun, 4 December 1893.

17. NMCL, John Macoun letterbooks. Macoun to Merriam, 29 March 1894.

18. Ibid. Macoun to Rhoads, 3 April 1894.

19. NMNS, Anderson papers. Merriam to Macoun, 3 April 1894.

20. NMCL, John Macoun letterbooks. Macoun to Merriam, 5 April 1894.

21. NMNS, Anderson papers. Merriam to Macoun, 2 May 1894.

22. NMCL, John Macoun letterbooks. Macoun to Merriam, 24 March 1896.

23. Published in two parts, the Catalogue of Canadian Birds (Ottawa, 1900; 1904) gave the name, range and breeding habits of all the known birds of Canada.

24. Sterling, op. cit., 230.

25. NMNS, Anderson papers. Merriam to Macoun, 16 February 1906 .

26. Ibid. Merriam to Macoun, 3 March 1906.

27. The one major exception was Dr Nils Kindberg of Sweden who examined Macoun's moss collections over several decades. 